\title{
Optimalisasi Gerakan Literasi Pada Santri Di Pondok Pesantren Ittihadul Ummah
}

\author{
Kharisma Nurul Fauziah ${ }^{* 1}$, Andhita Risko Faristiana ${ }^{2}$ \\ ${ }^{1}$ Hukum Keluarga Islam, Fakultas Syariah, Institut Agama Islam Negeri \\ Ponorogo \\ Jl. Puspita Jaya, Krajan, Pintu, Jenangan, Ponorogo 63492. \\ ${ }^{2}$ Komunikasi dan Penyiaran Islam, Fakultas Ushuluddin \\ Adab dan Dakwah, Institut Agama Islam Negeri Ponorogo \\ Jl. Puspita Jaya, Krajan, Pintu, Jenangan, Ponorogo \\ 63492.
}

Email: Kharismanurul31@gmail.com ${ }^{1}$, andhitarisko@iainponorogo.ac.id ${ }^{2}$

\begin{abstract}
Currently, the awareness of the importance of literacy among young people is very low. Whereas literacy is the ability to read and write. All knowledge can be known and even obtained by literacy. Literacy is a process of interaction or an ability within a person. Various readings that are now easy to access such as books, PDFs, journals, online libraries, and various other media are not able to arouse interest in reading, one of which is in Islamic boarding schools. The lack of available facilities is a major problem for all students at the Ittihadul Ummah Islamic Boarding School, especially among senior students. And in the end it causes enthusiasm or interest in reading students to decrease. This service activity with the Ulya santri literacy movement program at the Ittihadul Ummah Islamic Boarding School was carried out with the aim that all Ulya students were enthusiastic in literacy and could create works that could be seen by the general public. The approach method used is $A B C D$, which is an approach model by finding and utilizing the assets owned by the main target of the work program, namely Pondok Pesantren Ittihadul Ummah. The implementation of the work plan or program at the Ittihadul Ummah Islamic Boarding School, Banyudono Ponorogo was carried out well and smoothly according to the method used.
\end{abstract}

Keywords: Literacy, Islamic Boarding School, ABCD

\begin{abstract}
Abstrak
Saat ini kesadaran akan pentingnya berliterasi dikalangan anak muda terbilang sangat rendah. Padahal literasi merupakan sebuah kemampuan dalam membaca dan menulis. Semua ilmu pengetahuan dapat diketahui bahkan diperoleh dengan berliterasi. Literasi menjadikan suatu proses interaksi atau suatu kemampuan dalam diri seseorang. Berbagai bacaan yang sekarang mudah untuk diakses seperti buku, PDF, jurnal, perpustakaan online, maupun berbagai media lainnya tidak mampu menggugah selera minat baca, salah satunya di pondok Pesantren. Minimnya sarana yang tersedia menjadi problem utama bagi semua santri di Pondok Pesantren Ittihadul Ummah terutama kalangan santri ulya. Dan pada akhirnya menimbulkan semangat atau minat membaca santri menurun. Kegiatan pengabdian dengan program gerakan literasi santri ulya di Pondok Pesantren Ittihadul Ummah ini dilakukan bertujuan agar semua santri ulya semangat dalam berliterasi dan bisa menciptakan karya yang dapat dilihat oleh khalayak umum. Metode pendekatan yang digunakan adalah ABCD yaitu suatu model pendekatan dengan menemukan dan memanfaatkan terhadap aset yang dimiliki oleh sasaran utama program kerja, yaitu Pondok Pesantren Ittihadul Ummah. Pelaksanaan rencana atau program kerja di Pondok Pesantren Ittihadul Ummah Jarakan Banyudono Ponorogo terselenggara dengan baik dan lancar sesuai dengan metode yang digunakan.
\end{abstract}


Kata kunci: Literasi, Pesantren, $A B C D$

\section{PENDAHULUAN}

Indonesia merupakan sebuah negara kepulauan yang terdapat banyak sekali keragaman. Dikutip dari situs Badan Pusat Statistik(BPS), Indonesia adalah negara yang kaya "gemah ripah loh jinawl". Kekayaan itu tidak sebatas pada hasil alam saja, tetapi juga pada ragam budaya, suku bangsa, ras, bahasa daerah, dan juga agama. Meskipun kaya akan keragaman, mereka tetap satu Indonesia. Hal ini sesuai dengan Semboyan negara kita yaitu "Bhineka Tunggal Ika", yang mempunyai arti meskipun berbeda-beda tetap satu jua. Keberagaman bangsa Indonesia tidak hanya bisa dilihat dari jenis suku bangsanya saa, tetapi terlihat juga dari beragamnya agama yang dianut penduduknya ${ }^{1}$.

Pengakuan agama-agama yang ada di Indonesia dikukuhkan oleh Surat Keputusan Presiden Soekarno pada tahun 1965. Dalam Keppres itu, enam agama diakui secara resmi yaitu Islam, Protestan, Katolik, Hindu dan Konghucu. Pada tahun 1979, sidang kabinet masa Orde baru tidak mengakui agama Kong $\mathrm{Hu} \mathrm{Cu}$, sehingga agama tersebut tidak tercantum dalam sensus selanjutnya. Dan Indonesia adalah salah satu negara dengan muslim terbesar di dunia $^{2}$. Berdasarkan data Globalreligiusfuture, penduduk Indonesia yang beragama Islam pada tahun 2010 mencapai 209,12 juta jiwa atau sekitaran 87\% dari total populasi. Kemudian pada tahun 2020 penduduk muslim Indonesia diperkirakan akan mencapai 229,62 juta jiwa. ${ }^{3}$ Berangkat dari banyaknya warga muslim di Indonesia, kemudian lahirlah pesantrenpesantren yang digagas oleh tokoh-tokoh islam sebagai wadah pemikiran muslim yang berjuang untuk menghidupkan agama islam di Indonesia.

Secara umum perkembangan pesantren meningkat dengan cepat pada awal abad XX. Pondok pesantren merupakan lembaga pendidikan yang berbasis agama Islam tertua di Indonesia. Dengan beberapa faktor utamanya yaitu adanya wali songo, banyaknya orang yang pulang dari menunaikan ibadah haji, dan melalui transit para pedagang Islam dari negara Arab dan Gujarat, mereka menyelingi dagang sambil berdakwah. Sehingga tersebarlah agama Islam dengan mudah dan diterima secara damai oleh masyarakat tersebut. Kehadiran pesantren memberikan pengaruh yang sangat besar terhadap negara Indonesia. Pondok pesantren juga banyak melahirkan para tokok-tokoh Islam yang mampu memimpin negara, Diantaranya, KH. Hasyim As'ary, Gus Dur, dan masih banyak lagi tokoh-tokoh Islam yang mampu berperan untuk negara kita ${ }^{4}$.

Adapun Pesantren sendiri merupakan sebuah pendidikan Islam tradisional yang mempelajari ilmu agama dengan penekanan pada pembentukan moral dan akhlak santri agar bisa mengamalkanya dengan bimbingan kyai dan menjadikan kitab kuning sebagai sumber primer serta masjid sebagai pusat kegiatannya ${ }^{5}$.

\footnotetext{
${ }^{1}$ https:www.Kompas.com/skola/read/2020/03/20/120000169/keberagaman-suku-bangsa-di-Indonesia?page=3

${ }^{2}$ Hasbullah, Moeflich. Sejarah Sosial Intelektual Islam Indonesia,(Pustaka Setia, 2012) Hal 15

3https://databoks.katadata.co.id/datapublish/2019/09/25/indonesia-negara-dengan-penduduk-muslim-terbesardunia

${ }^{4}$ Abu Maskur, "Penguatan Budaya Literasi di Pesantren”, IQ (Ilmu Al-Qur'an): Jurnal Pendidikan Islam vol.2, no.1 (2019): $1-16$

${ }^{5}$ https://www.kanalpengetahuan.com/pengertian-pondok-pesantren
} 
Kementrian Agama mencatat ada 26.973 pondok pesantren yang tersebar di seluruh provinsi di Indonesia. Jawa Barat memiliki jumlah paling banyak yakni sekitaran 8.343 pondok pesantren, lalu diikuti oleh Banten, jawa Timur dan Jawa Tengah kisaran 3-4 ribu pondok pesantren. Di Jawa Timur sendiri jumlah pesantren sekitaran 4.718 lembaga. Adapun Pesantren besar di Jawa Timur diantaranya Pondok Pesantren Sidogiri (Pasuruan), Pondok Pesantren Langitan (Tuban), Pondok Pesantren Lirboyo (Kediri), Pondok Pesantren Tebuireng (Jombang), dan Pondok Pesantren di Ponorogo yaitu Darussalam Gontor ${ }^{6}$. Selain Darussalam Gontor di Ponorogo juga banyak sekali pesantren- pesantren lainnya, hingga Ponorogo dikenal sebagai Kota Santri, dengan alasan banyaknya pesantren di daerah tersebut. Pesantren sejatinya memiliki tiga corak yang berbeda- beda, yakni corak tradisional, modern, dan salafi. Di kabupaten Ponorogo Pesantren yang bercorak modern seperti Pondok Pesantren Al- Iman, Wali Songo, dan Darussalam Gontor tadi. Sedangkan pesantren tradisional dan salafi seperti Pondok Pesantren Darul Huda, Hudatul Muna, Ittihadul Ummah, dan masih banyak lagi ${ }^{7}$.

Pondok Pesantren salafiyah umumnya hanya terfokus dalam mendalami ilmu agama dengan memaknai kitab kuning, mengadakan sorogan kitab, syawir, dan juga bermunajahah, namun berbeda halnya dengan Pondok Pesantren yang satu ini, namanya Pondok Pesantren Ittihadul Ummahyang terletak di jln Soekarno Hatta Gg VI Nomor 24. Pondok Pesantren "Ittihadul Ummah" Jarakan Banyudono Ponorogo berdiri pada tahun 1972 dimulai dengan bentuk dan aktivitas yang sederhana. Awal mula Pondok Pesantren ini bernama "Wahdatul Ummah" kemudian pada tahun 1980 dirubah menjadi "Ittihadul Ummah". Sedangkan "yayasan" sebagai payung hukum kelembagaan baru terbentuk pada tanggal 11 Januari 1992 dengan lahirnya Yayasan Al-Ittihad berdasarkan SK Notaris Ny. Kustini Sosrokusumo, SH No.3. Sekretariat yayasan tersebut beralamat di jalan S. Ageng tirtoyoso No. 47 Ponorogo.

Pondok Pesantren Ittihadul Ummah ini, Menjadi salah satu unit dari Yayasan ALIttihad Ponorogo, yang didalamnya juga terdapat : Pendidikan Anak Usia Dini (PAUD) Roudhoh, Madrasah Diniah Al-jariyah Ula, Madrasah Diniah Al-Jariyah Wustho, MTs Ma'arif 1 Ponorogo, Madrasah Aliyah Ma'arif Nahdlatul Ummah, dan juga LKSA Ittihadul Inayah ${ }^{8}$.

Melihat adanya kemajuan teknologi yang semakin canggih yang mampu memudahkan manusia, justru bertolak belakang dengan fungsinya. Berbagai bacaan yang sekarang mudah untuk diakses seperti Buku berbentuk PDF, jurnal, perpustakaan online, maupun berbagai media lainnya tidak mampu menggugah selera minat baca remaja saat ini terutama dari kalangan pelajar. Bahkan kemajuan teknologi sekarang banyak dipersalah gunakan oleh banyak orang. Minimnya kesadaran para remaja Indonesia dalam berliterasi, menjadikan sebuah fakta mengenai tingkat berliterasi di Indonesia terbilang sangat rendah. Bahkan peringkat terbawah diantara negara- negara lain. Berdasarkan hasil surve yang dilakukan program for International Student Assesment (PISA) yang dirilis Organization for Economic coperation and Development (OECD) pada tahun 2019. Tingkat literasi pada penelitian di 70 negara berada di nomer 62 atau berada di 10 negara terbawah yang memiliki tingkat literasi terendah. Dari adanya fenomena tersebut,Untuk meningkatkan minat baca para remaja, maka diperlukan suatu gerakan membudayakan literasi di suatu kelompok atau tempat tersebut. Menurut Musthafa tradisi membaca bukan hanya sekedar pintu masuk

${ }^{6}$ https://www.google.com/search?=daftar+pondok+Pesantren + di + Jawa + timur\&oq=\&aqs=chrome. 2

${ }^{7}$ H.A. Rodli Makmun, Pembentukan Karakter Berbasis Pendidikan Pesantren, Vol. 12 No. 2, (Desember 2014): 214

${ }^{8}$ KH. Imam Sayuti Farid, Geneologi, (Yogyakarta; Nadi Pustaka, 2020), 369-370 
untuk memperluas sebuah wawasan atau meningkatkan suatu keilmuan tertentu, tetapi tradisi membaca merupakan langkah awal untuk membangun sebuah tradisi keilmuan yang mengembangkan beberapa aspek seperti meneliti, menelaah, dan berfikir secara cermat dalam menghadapi suatu masalah. ${ }^{9}$

Literasi sendiri merupakan sebuah kemampuan dalam membaca dan menulis. Semua ilmu pengetahuan dapat diketahui bahkan diperoleh dengan berliterasi. Literasi menjadikan suatu proses interaksi atau suatu kemampuan dalam diri seseorang kaitanya dalam hal membaca, menulis, berbicara, bahkan sampai memecahkan suatu permasalahan. Literasi juga diartikan sebagai melek huruf atau kecakapan dalam membaca dan menulis. Sedangkan lawan dari kata illiterateadalah buta huruf. Menurut Nopilda dan Kristiawan memaknai literasi sebagai kemampuan seseorang dalam memaknai bahan bacaan yang berawal dari kegiatan penelusuran, pencarian, pengolahan, dan memahami informasi dari sumber bacaan. Seperti yang disampaikan oleh Permatasari bahwa kualitas suatu bangsa itu ditentukan oleh kercerdasan dan pengetahuannya, sedangkan kercerdasan dan pengetahuan dapat diperoleh dari seberapa ilmu pengetahuan yang diperoleh baik secara lisan maupun tulisan ${ }^{10}$.

Gerakan literasi di pesantren merupakan suatu kegiatan yang sifatnya partisipasi dengan melibatkan warga pesantren dengan dukungan para elemen di dalamnya. Melihat minat baca para pemuda saat ini, pengasuh Pondok terutama Ust. Nastain berinisiatifmengajak para santrinya untuk meningkatkan kualitas membaca di Pondok Pesantren Itihadul Ummah. Terutama lebih menekankan dari kalangan mahasiswa.Sejak tahun 2020 pengasuh pondok menghimbau santriwan dan santriwatinya untuk lebih menyukai dan giat berliterasi.Adapun kegiatan yang diselenggarakan berupa menulis hasil kesimpulan dari buku atau bacaan yang telah dibaca kemudian ditulis pada google form yang telah di sediakan. Adapun buku yang dibaca tersebut yang mengandung sebuah kemanfaatan bagi setiap individunya. Contohnya buku biografi para tokoh- tokoh, buku pelajaran, dan lainnya. Namun, saat melakukan pengamatan pengabdi menemukan beberapa faktor yang menyebabkan kegiatan membaca tersebut belum berjalan sesuai yang diharapkan. Seperti: 1) kurangnya tenaga pendampingan saat membaca, 2). tidak adanya hukuman bagi yang tidak membaca, 3). serta kurang keefektifan dalam pengelolaan kegiatan tersebut.

Sebagai salah satu kegiatan pengabdian kepada masyarakat ini, pengabdi bersama Pengasuh Pondok Pesantren, dan bekerja sama dengan pengurusnya ingin mengembangkan metode yang sudah ada, yaitu berliterasi melalui blog Gurusiana untuk santriwan dan santriwati yang membawa alat elektronik berupa telepon seluler dan laptop. Adapun kegiatan literasi untuk kalangan siswa MTs dan SMA dilakukan setelah jam madrasah malam dengan membaca minimal 15 menit. Adapun literasi Gurusiana santri ulya (santri pasca SMA) di Pondok Pesantren tersebut merupakan kegiatan wajib yang harus dilakukan, untuk mengantisipasi penggunaan telepon seluler yang kurang bermanfaat, dan harapannya juga bertujuan untuk menyebar kebaikan melalui media digital, menginformasikan berita-berita terbaru, menumpahkan ide-ide terbaik melalui blog Gurusiana tersebut. Seperti artikel, puisi, resensi, dan cerpen. Penelitian ini diharapkan dapatmeningkatkan daya tarik literasi dan

\footnotetext{
${ }^{9}$ M. Maribun, “Minat Membaca dan Implementasinya dalam Bimbingan dan Konseling”. ENLIGHTEN, Jurnal Bimbingan Konseling Islam2, no.2 (2019): 78-84

${ }^{10}$ Mursalin, "Penumbuban Budaya Literasi Dengan Penerapan Ilmu Keterampilan Berbahasa (Membaca Dan Menulis)", vol.3, no. 1 (Juni 2017):33
} 
keaktifan santri di dalam program terebut, juga mengharap seluruh santri tidak tertinggal dengan kemajuan zaman yang serba digital ini ${ }^{11}$.

Konsep pengabdian masyarakat yang dilakukan olehBaharun dan Rizqiyahdalam jurnal pendidikan Islam yang berjudul "Melejitkan Ghirah Belajar Santri Melalui Budaya Literasi Di Pondok Pesantren" hal ini mencoba untuk menerapkan pembiasaan diri agar lebih giat dalam membaca dan menulis agar budaya literasi tetap berjalan sehingga lama kelamaan akan menciptakan dan menghasilkan sebuah karya ${ }^{12}$.

Peneliti selanjutnya yang dilakukan oleh Machsun Rifauddin, Novi Nur Ariyanti, dan Bagas Aldi Pratama, yang melakukan penelitian dengan judul "Pembinaan Literasi Di Pondok Pesantren Sebagai Bekal Santri Hidup Bermasyarakat". Pondok Pesantren tersebut memiliki cara tersendiri dalam menekankan budaya literasi pada santrinya. Budaya literasi tidak hanya semata- mata sebagai formalitas saja, namun sebagai investasi masa depan seorang santri agar kelak siap dalam menghadapi kehidupan bermasyarakat ${ }^{13}$.

\section{METODE}

\section{Asset Based Community Development (ABCD)}

Gerakan literasi di pondok Pesantren Ittihadul Ummah ini menggunakan Asset Based Community Development $(\mathrm{ABCD})$ yang mengutamakan pemanfaatan asset dan potensi yang ada disekitar dan dimilki oleh komunitas masyarakat. Komunitas masyarakat dalam hal ini yaitu sebuah pesantren yang sudah mempunyai 4 lembaga pendidikan di jenjang Paud/Tk, Mts dan MA yang di bawah naungan langsung yayasan Pondok Pesantren AlITTIHAD "Ittihadul Ummah". Jarakan, Banyudono, Ponorogo. Pesantren sendiri merupakan lembaga pendidikan yang sangat utama, karena lembaga keagamaan yang memberikan pendidikan sekaligus pengajaran dalam mengembangkan dan santri kemudian mempelajari agama dari seorang kyai.

Pondok Pesantren Ittihadul Ummah Jarakan Banyudono Ponorogo sendiri mempunyai potensi yang bisa dikembangkan lagi dalam proses meningkatkan minat baca santri. Potensi- potensi tersebut diantaranya pertama, Jumlah santri yang semakin banyak, kedua, salah satu aset yang sudah dimiliki pondok adalah bangunan perpustakaan sebagai penunjang santri dalam berliterasi, ketiga, buku- buku bacaan yang tersedia di pondok sudah memenuhi persyaratan yaitu layak dibaca oleh santri, dan buku- buku tersebut tidak hanya mencangkup agama saja melainkan yang umum juga. Meskipun dalam hal itu beberapa aset sudah banyak tepenuhi, namun masih terdapat kelemahan-kelemahannya yang ditemukan peneliti saat melakukan observasi awal, diantaranya yaitu: pertama, Meskipun sudah mempunyai perpustakaan sendiri, namun masih kurang ruang dan luas karena jumlah santri yang semakin banyak, sehingga menimbulkan ketidak nyamanan dalam membaca buku, kedua, kesadaran minat baca santri yang semakin menurun.

Berdasarkan pemaparan diatas, peneliti akhirnya memutuskan untuk mengadakan kegiatan yang dapat membangkitkan semangat dan daya tarik santri dalam berliterasi.

\footnotetext{
${ }^{11}$ Wawancara dengan Ust. Nastain, Pengasuh pondok Pesantren Ittihadul Ummah 7 Juli 2021 20:00 WIB

${ }^{12}$ Baharun, dan Rizqiyah, "Melejitkan Ghiroh Belajar Santri Melalui Budaya Literasi di Pesantren", TADRIS: Jurnal Terkait Kegiatan Pengabdian Kepada Masyarakat, terkhusus bidang Pendidikan Islam,15(1),https://doi.org/10.19105/tipi.v15i1.3048/ 108-117

${ }^{13}$ Machsun Rifauddin, Novi Nur Ariyanti, dan Bagas Aldi Pratama, "Pembinaan Literasi Di Pondok Pesantren Sebagai Bekal Santri Hidup Bermasyarakat”, Info Bibliotheca: Jurnal Terkait Kegiatan Pengabdian Kepada Masyarakat, terkhusus bidang perpustakaan dan Ilmu informasi, Vol 1, no 2 (Juni 2020): 99-111
} 
Sehingga santri bisa semakin sadar akan pentingnya membaca, Karena dengan membaca kita tidak hanya memperluas wawasan tetapi juga mengenali dunia dan seisinya. Dalam metode $A B C D$ ini mempunyai lima tahapan untuk melakukan riset pendampingan.

Dalam metode $A B C D$ memiliki lima langkah kunci untuk melakukan riset proses pendampingan.

Tahap 1: Inkulturasi (Perkenalan)

Pada tahap ini dilakukan sebelum kegiatan Kuliah Pengabdian Masyarakat dimulai, Mahasiswa IAIN Ponorogo sebagai peserta KPM melakukan izin terkait kegiatan KPM yang akan dilaksanakan di Pondok Pesantren Ittihadul Ummah Jarakan Banyudono Ponorogo. Peserta KPM memohon izin untuk memperkenalkan sekaligus menjelaskan maksud kepada pihak pengasuh pondok untuk meminta izin melaksanakan kegiatan KPM di pondok. Selain itu peserta KPM juga mengutarakan kegiatan- kegiatan apa saja yang akan dilakukan dalam kegiatan Kuliah Pengabdian Masyarakat di pondok. Titik fokus yang dijadikan program utama kegiatan ini juga disampaikan kepada pengasuh pondok pesantren. Pada saat melakukan perizinan, pengasuh pondok memberikan penjelasan dan gambaran yang berkaitan dengan pondok pesatren Ittihadul Ummah tersebut.

Selanjutnya pada tahapan ini peserta KPM sekaligus menentukan objek yang akan dijadikan sasaran utama dalam program kegiatan ini. Sasaran utamanya adalah santri yang sudah lulus dari MA yang sudah boleh membawa alat elektronik seperti hp dan laptop. Peserta KPM juga meminta izin kepada penanggung jawabnya secara langsung untuk melakukan sosialisasi terhadap anggotanya. Setelah mendapatkan perizinan dari pihak-pihak pondok, peserta KPM menentukan waktu pelaksanaan kegiatan dan dalam hal ini, pengasuh langsung memberikan persetujuan.

Tahap 2: Discovery (Mengungkapkan Informasi)

Pada tahapan ini peserta KPM melakukan beberapa wawancara dengan pengasuh sekaligus pengurus pondok pesantren Ittihadul Ummah. Pengasuh dan beberapa pengurus menjelaskan terkait aset- aset dan kegiatan yang sudah ada di pondok. Dalam hal ini peserta KPM mencari informasi terkait budaya membaca santri yang ada di pondok pesantren Ittihadul Ummah. Karena hal itu yang berkaitan dengan program utama yang akan dijalankan oleh peserta KPM.

Setelah selesai melakukan silaturahmi dan wawancara terhadap pengasuh sekaligus pengurus pondok pesantren Ittihadul Ummah dapat diketahui bahwa budaya membaca pada santri ternyata sangat kecil dan masih minim kesadaran minat dalam membaca. Selain itu, peserta KPM juga menggali informasi terkait faktor- faktor apa saja yang menyebabkan budaya membaca santri di pesantren Ittihadul Ummah masih belum berjalan sesuai harapan pengasuhnya. Rata- rata faktor yang menyebabkan santri banyak yang belum sadar akan pentingnya budaya membaca adalah pertama,karena buku yang tersedia kurang banyak jika dibandingkan dengan jumlah santri yang semakin bertambah, kedua,kurangnya luas ruang perpustakaan hingga menyebabkan santri tidak nyaman ketika membaca di dalam perpustakaan tersebut.

Terkait beberapa faktor tersebut, hal ini menjadi permasalahan yang sangat serius yang perlu ditindak lanjuti. Pengasuh berharap dengan adanya Kegiatan Pengabdian Masyarakat di pondok pesantren Ittihadul Ummah ini peserta KPM dapat membantu secara maksimal selama proses kegiatan berlangsung dan tentunya program yang akan dijalankan 
dapat berjalan dengan lancar, juga bermanfaat bagi semua santri, dan bisa istiqomah dalam jangka waktu yang panjang.

Tahap 3: Design (Mengetahui Aset dan Mengidentifikasi Peluang)

Pada tahap ini peneliti melakukan observasi terkait beberapa aset dan potensi apa saja yang dimiliki pondok pesantren Ittihadul Ummah. Setelah mengetahui aset yang dimiliki pondok pesantren Ittihadul Ummah, peneliti mulai merencanakan program kerja apa saja untuk menggali potensi para santri dan hasilnya pun berbeda- beda antara santri satu dengan santri lainnya. Kemudia, peneliti bersama pengasuh sekaligus pengurus bagian penanggung jawab dibidang tersebut bekerja sama, mengenaibagaimana cara mengabungkan antara potensi santri yang berbeda- beda tersebut agar menjadi satu sesuai dengan program kegiatan yang akan dijalankan sekaligus mengatur waktu pelaksanaanya.

Tahap selanjutnya yaitu melakukan pembiasaan agar dilakukan oleh masing- masing santri. Adapun yang menjadi sasaran utamanya adalah santri ulya pasca MA. Pembiasaan karakter harus dilakukan agar santri pondok pesantren Ittihadul Ummah mempunyai rasa tanggung jawab dan memiliki kebiasaan membaca yang baik sehingga kelak dapat diterapkan dalam kehidupan sehari-harinya.

Tahap 4: Define (Mendukung Keterlaksanaan Program Kerja)

Pada tahap ini peserta KPM melakukan eksekusi program kerja atau pelaksanaan rencana kerja. Pertama peserta bersama pengasuh pondok pesantren Ittihadul Ummah melakukan sosialisasi terkait kegiatan yang akan dilakukan oleh para santri ulya pasca MA tersebut. Adapun kegiatan sosialisasi dilaksanakan pada malam hari sekitar jam 20:30 WIB setelah mengaji bertempat di aula putra pondok pesantren Ittihadul Ummah Jarakan Banyudono Ponorogo. Peserta KPM menyampaikan program kerja yang akan dilaksanakan. Dalam proses penyampain program kerja dibantu oleh pengasuh pondok pesantren Ittihadul ummah. Untuk mengawali agar budaya membaca santri berjalan, Peserta KPM mengadakan pengisian absebsi membaca. Karena semua berawal dari adanya tuntutan yang lama kelamaan akan menjadi sebuah kebiasaan yang akan dijalankan dikehidupan sehari-harinya. Dan diakhir bulan nanti akan diadakan rekapan absen membaca. Jadi santri yang tidak membaca dalam sehari akan kelihatan. Kemudian, sebagai penganti karena tidak membaca nanti ada konsekuensi tersendiri sesuai dengan hasil kesepakatan bersama.

Tahap 5: Refelection (Refleksi)

Pada tahap ini refleksi kegiatan kerja yang telah direncanakan peserta KPM. Dalam program kerja tersebut para pengasuh, pengurus, serta santri ulya pasca MA pondok pesantren Ittihadul Ummah sangat berantusias ikut serta membantu dalam kegiatan tersebut. Para santri lama kelamaan menjadi sadar akan pentingnya budaya membaca dan semakin tertarik tanpa ada paksaan dari pihak manapun. Ada yang mengatakan semakin banyak membaca seolah- olah buku yang dibaca tersebut menjadi semakin nagih untuk dibaca. Buku- buku yang dibaca bisa berupa fiksi dan non fiksi, apapun yang dibaca harapanya semoga bisa menambah wawasan yang luas dan memberikan kemanfaatan bagi setiap santri.

\section{Teknik- Teknik Pendampingan}

Metode dan alat untuk memobilisasi aset pemberdayaan masyarakat melalui Asset Based Community Driven Development (ABCD), antara lain:

a. Penemuan Apresiatif (Appresiatif Inquiry)

Appreciative Inquiry (AI) adalah cara yang positif untuk melakukan perubahan organisasi berdasarkan asumsi yang sederhana yaitu bahwa setiap organisasi memiliki sesuatu yang 
dapat bekerja dengan baik, sesuatu yang menjadikan organisasi hidup, efektif dan berhasil, serta menghubungkan organisasi tersebut dengan komunitas dan stakeholdernyadengancara yang sehat. ${ }^{14} \mathrm{AI}$ ini diwujudkan dengan adanya Forum Group Discussion (FGD) yang dilakukan pada jenjangnya masing-masing.

Adapun secara teknis mekanisme pemberdayaan dengan memakai proses Appreciative Inquiry (AI) terdiri dari 4 tahap yaitu Discovery, Dream, Design, dan Destiny atau sering disebut Model atau Siklus 4-D. ${ }^{15}$

1. Discovery

Tahap Discovery adalah proses pencaharian yang mendalam tentang hal-hal positif, hal-hal terbaik yang pernah dicapai, dan pengalaman-pengalaman keberhasilan di masa lalu, Proses ini dilakukan dengan wawancara apresiatif.

2. Dream

Pada tahap ini, setiap orang mengeksplorasikan harapan dan impian mereka baik untuk diri mereka sendiri maupun untuk organisasi. Inilah saatnya orang-orang memikirkan hal-hal besar dan berpikir out of the box serta membayangkan hasil-hasil yang ingin dicapai.

3. Design

Pada tahap ini, orang mulai merumuskan strategi, proses dan sistem, membuat keputusan dan mengembangkan kolaborasi yang mendukung terwujudnya perubahan yang diharapkan.

4. Destiny

Tahap dimana setiap orang dalam organisasi mengimplementasikan berbagai hal yang sudah dirumuskan pada tahap design. Tahap ini berlangsung ketika organisasi secara kontinyu menjalankan perubahan, memantau perkembangannya, dan mengembangkan dialog, pembelajaran dan inovasi-inovasi baru. ${ }^{16}$

a. Pemetaan Komunitas (Community Mapping)

Community map adalah Pendekatan atau cara untuk memperluas akses ke pengetahuan lokal. Community map merupakan visualisasi pengetahuan dan persepsi berbasis masyarakat mendorong pertukaran informasi dan menyetarakan bagi semua masyarakat untuk berpartisipasi dalam proses yang mempengaruhi lingkungan dan hidup mereka. ${ }^{17}$

b. Penelusuran Wilayah (Transect)

Transect adalah garis imajiner sepanjang suatu area tertentu untuk menangkap keragaman sebanyak mungkin. Dengan berjalan sepanjang garis itu dan mendokumentasikan hasil pengamatan, penilaian terhadap berbagai asset dan peluang dapat dilakukan. Penelusuran wilayah dilakukan bebarengan dengan pemetaan komunitas (community mapping). ${ }^{18}$

c. Pemetaan Asosiasi dan Institusi

Asosiasi merupakan proses interaksi yang mendasari terbentuknya lembaga-lembaga sosial yang terbentuk karena memenuhi faktor-faktor sebagai berikut: 1) kesadaran akan

\footnotetext{
${ }^{14}$ NadhirSalahudin, dkk. Panduan KKN ABCD UIN SunanAmpel Surabaya, (Surabaya: LP2M UIN SunanAmpel Surabaya, 2015), 46.

${ }^{15}$ Pedoman KPM-DDR 2021 Institut Agama Islam NegeriPonorogo, (Ponorogo: LPPM IAIN Ponorogo, 2021), 50.

${ }^{16}$ Pedoman KPM-DDR 2021 Institut Agama Islam Negeri Ponorogo, (Ponorogo: LPPM IAIN Ponorogo, 2021), 50-51.

${ }^{17}$ Ibid., 54

${ }^{18}$ Nadhir Salahudin, dkk. Panduan KKN ABCD UIN Sunan Ampel Surabaya, (Surabaya: LP2M UIN Sunan Ampel Surabaya, 2015), 38
} 
kondisi yang sama, 2) adanya relasi sosial, 3) dan orientasi pada tujuan yang telah ditentukan. ${ }^{19}$

d. Pemetaan Aset Individu (Individual Inventory Skill)

Metode atau alat yang dapat digunakan untuk melakukan pemetaan individual asset antara lain kuisioner, interview dan focusgroupdiscussion. Manfaat dari pemetaan asset individual asset antara lain: 1) Membantu membangun landasan untuk memberdayakan masyarakat dan memiliki solidaritas yang tinggi dalam masyarakat, 2) Membantu membangun hubungan yang baik dengan masyarakat, 3) Membantu masyarakat mengidentifikasi keterampilan dan bakat mereka sendiri. ${ }^{20}$

e. Sirkulasi Keuangan (Leacky Bucket)

Perputaran ekonomi yang berupa kas, barang dan jasa merupakan hal yang tidak terpisahkan dari komunitas dalam kehidupan mereka sehari-hari. Seberapa jauh tingkat dinaminitas dalam pengembangan ekonomi lokal mereka dapat dilihat, seberapa banyak kekuatan ekonomi yang masuk dan keluar. Untuk mengenali, mengembangkan dan memobilisir asset-asset tersebut dalam ekonomi komunitas atau warga lokal diperlukan sebuah analisa dan pemahaman yang cermat. Salah satu pendekatan yang digunakan dalam pendekatan ABCD adalah melalui Leacky Bucket. ${ }^{21}$

f. Skala Prioritas (Low Banging Fruit)

Setelah masyarakat mengetahui potensi, kekuatan dan peluang yang mereka miliki dengan melalui menemukan informasi dengan santun, pemetaan asset, penelusuran wilayah, pemetaan kelompok atau institusi dan mereka sudah membangun mimpi yang indah maka langkah berikutnya adalah bagaimana mereka bisa melakukan semua mimpi-mimpi diatas, karena keterbatasan ruang dan waktu maka tidak mungkin semua mimpi mereka diwujudkan. ${ }^{22}$

\section{HASIL DAN PEMBAHASAN}

\section{Pelaksanaan Pengabdian}

Langkah awal dalam kegiatan Kuliah Pengabdian Masyarakat ini, peserta KPM melakukan observasi dengan terjun secara langsung ke lokasi yang akan dijadikan kegiatan pengabdian. Adapun lokasi pengabdian yang dituju adalah di pondok pesantren Ittihadul Ummah Jarakan Banyudono Ponorogo. Pondok pesantren Ittihadul Ummah sendiri merupakan pondok pesantren berbasis salafiyah yang berada dikota Ponorogo. Dengan KH. Imam Sayuti Farid sebagai pendiri pondok pesantren Ittihadul Ummah sekaligus Ust. Nastain dan Ust. Kirom sebagai pengasuhnya.

Dari hasil observasi yang telah dilakukan, beberapa aset dan potensi yang dimiliki di pondok pesantren Ittihadul Ummah peserta KPM lebih memfokuskan melakukan kegiatan terkait budaya berliterasi pada santri. Adanya minat baca yang sangat menurun bahkan ditingkat paling rendah menjadikan sasaran utama dalam program rencana kerja peserta KPM ini. tujuanya agar santri memiliki daya tarik dalam membaca buku terutama

\footnotetext{
${ }^{19}$ Soetomo, Pembangunan Masyarakat, (Yogyakarta: Pustaka Pelajar, 2009), 41

${ }^{20}$ Nadhir Salahudin, dkk. Panduan KKN ABCD UIN Sunan Ampel Surabaya, (Surabaya: LP2M UIN Sunan Ampel Surabaya, 2015), 42

21 Pedoman KPM-DDR 2021 Institut Agama Islam Negeri Ponorogo, (Ponorogo: LPPM IAIN Ponorogo, 2021), 63

22 Ibid., 69
} 
santri ulya pasca MA. Peserta KPM juga berkoordinasi dengan pengasuh sekaligus pengurus pondok pesantren Ittihadul Ummah.

\section{Gambaran Kegiatan Pengabdian}

Sebelum Kuliah Pengabdian Masyarakat berlangsung sudah ada rencana terkait kegiatan yang akan dilaksanakan. Tahap awal yang dilakukan peserta KPM yaitu konsultasi dengan dosen pembimbing lapangan (DPL) terkait lokasi yang akan dijadikan sasaran dan segala aspek yang tersedia di lokasi tersebut. Setelah melakukan konsultasi dengan dosen pembimbing lapangan, langkah selanjutnya, peserta KPM menuju tempat yang akan dijadikan titik fokus kegiatan pengabdian ini. Adapun kegiatan observasi ini bertujuan untuk mengetahui aset- aset dan potensi apa saja yang ada di pondok pesantren Ittihadul Ummah baru kemudian melakukan kerjasama dengan beberapa pihak yang berkaitan dengan kegiatan pengabdian yang akan dilaksanakan.

Setelah mendapat izin untuk melakukan kegiatan pengabdian di pondok pesantren Ittihadul ummah ini, selanjutnya peserta KPM melakukan tindak lanjut penentuan hari dan waktu pelaksanaan program kerja. Sebelumnya peserta juga sudah diberikan izin terkait program kerja yang akan dilaksanakan dan titik fokus yang akan menjadi sasaran dalam kegiatan ini. Peserta KPM juga berkerja sama dengan pengurus pondok pesantren Ittihadul Ummah untuk mempersiapkan hal- hal yang akan dibutuhkan ketika melaksanakan program kerja yang akan dijalankan.

Saat akan melakukan sosialisasi terhadap santri di pondok pesantren Ittihadul Ummah, peserta KPM berkoordinasi dengan pengasuh pondok terkait dengan hal- hal yang akan disampaikan dalam kegiatan tersebut. Mulai dari pengenalan kegiatan, penjelasan yang berkaitan dengan budaya literasi, dan memberikan konsekuensi kepada santri jika melanggarnya. Pada saat melakukan sosialisasi ini peserta KPM didampingi pengasuh pondok pesantren Ittihadul Ummah Ust. Nastain juga menambahi penjelaskan mengenai beberapa hal yang berkaitan dengan kegiatan yang akan dilaksanakan kepada santri ulya pasca MA pondok pesantren Ittihadul Ummah. Sehingga ada penguatan lebih yang bisa mendorong para santri untuk gemar dalam membaca.

\section{Gambar 1: Foto Kegiatan Pendampingan Mengenai Cara Membuat Karya Di Guru Siana}



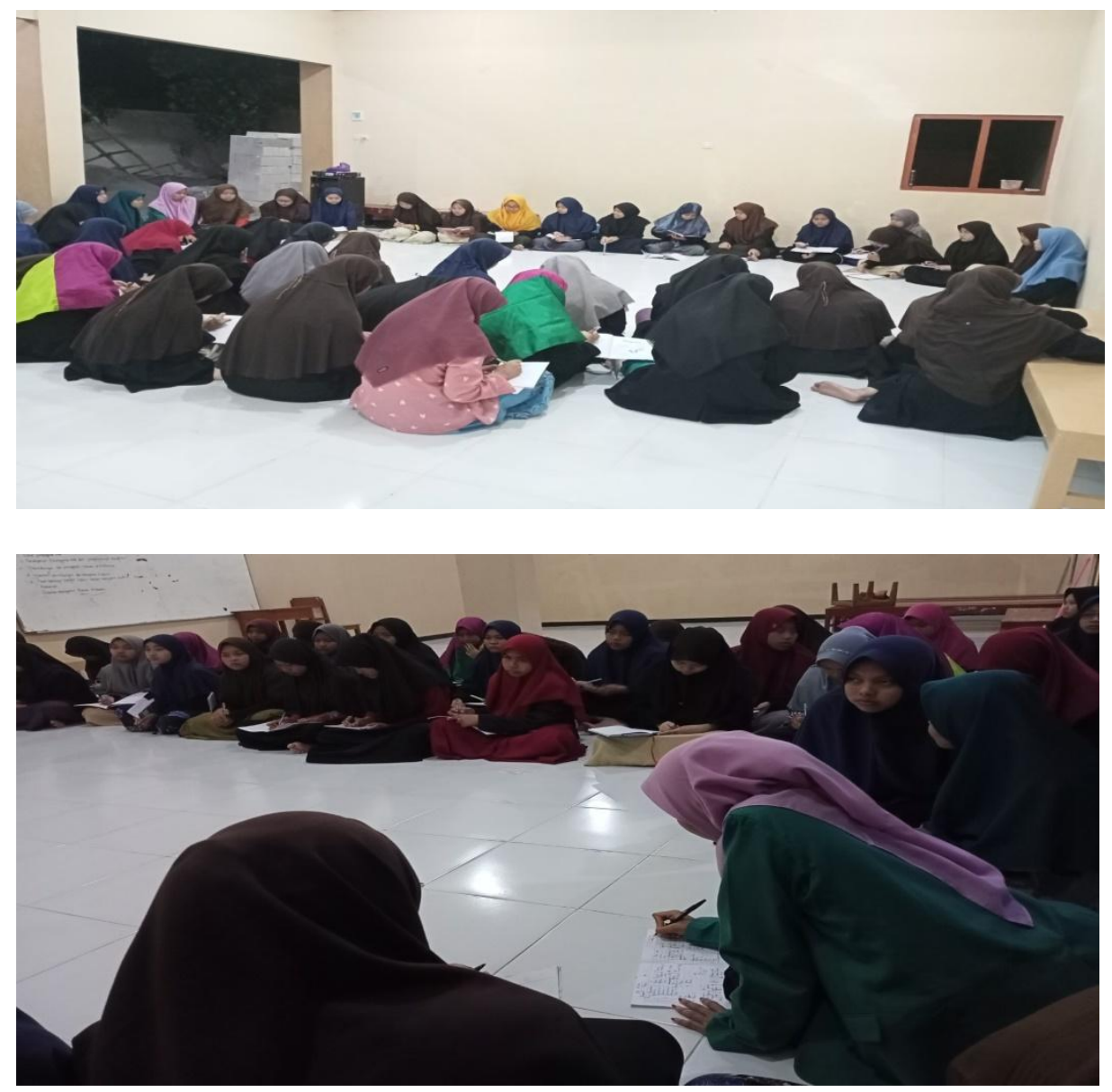

Pendampingan ini dilakukan sebanyak satu minggu sekali, yaitu pada hari Selasa dan Sabtu.

Saat melakukan pendampingan kepada santri ulya pondok pesantren Ittihadul ummah, para santri diharuskan membawa buku bacaan yang akan mereka baca. Setelah menjelaskan terkait kegiatan pendampingan ini, para santri diharuskan membuat karya yang kemudian di tulis di blok bernama Guru Siana. Guru Siana sendiri adalah sebuah blok media yang menampung karya yang berbentuk puisi, artikel, resensi, cerpen, dan masih banyak lagi kumpulan-kumpulan karya yang bisa dipublikasikan. Para santri diharapkan menulis karya di Guru Siana ini minimal tiga kali dalam seminggu. Tujuannya agar para santri selain membaca juga terampil dan kreatif dalam membuat karya yang bisa dibaca oleh khalayak umum.

\section{Jalannya pelaksanaan Kegiatan dan Hasil Kegiatan}

Pelaksanaan kegiatan pengabdian ini dimulai setelah mendapat izin dari Pengasuh pondok pesantren Ittihadul Ummah. Pada saat melakukan silaturahmi atau sowan, peserta KPM meminta izin untuk melakukan kegiatan KPM di tempat ini, peserta KPM dan Ust Nastain selaku pengasuh pondok berdiskusi terkait aset- aset dan potensi apa saja yang sudah ada. Pengasuh juga menjelaskan beberapa kelemahan dan kendala apa saja yang ada di pondok pesantren Ittihadul ummah ini. Sehingga peserta KPM mempunyai gambaran terkait hasil pemaparan yang sudah dijelaskan oleh pengasuh pondok tadi. Tidak hanya minta izin kepada pengasuh pondok saja, tetapi pengabdi juga bekerja sama dengan pengurus untuk membantu jalannya program kerja yang akan dilaksanakan nanti. 
kurangnya minat baca santri di pondok pesantren Ittihadul Ummah ini, menjadi salah satu permasalahan yang harus segera ditangani. Karena pemuda saat ini lebih tertarik ke gadget dari pada buku-buku. Pengasuh juga khawatir jika santri- santri di pondok pesantren Ittihadul Ummah ini terbawa arus globalisasi yang semakin canggih ini. Karena semakin mudah dalam bersosial media menjadikan mereka enggan untuk membaca buku, bahkan budaya berliterasi di pondok pesantren Ittihadul ummah sangat jarang ditemukan.

Sebelum melaksanakan kegiatan pengabdian, Peserta KPM yang sudah bekerja sama dengan pengasuh sekaligus pengurus pondok, memberikan arahan- arahan terkait program kerja yang akan dilakukan nantinya kepada santri ulya pasca MA di pondok pesantren Ittihadul Ummah ini. Adapun waktu pelaksanaanya pada tanggal 9 Juli 2021 jam 20:00 WIB dan bertempat di gedung aula putra.

Pada saat memberikan arahan tersebut, peserta KPM sekaligus didampingi oleh pengasuh pondok memberikan penjelasan-penjelasan yang cukup jelas kepada santri ulya. Hari berikutnya peserta KPM mendampingi santri ulya dalam kegiatan membaca buku-buku yang sudah tersedia di perpustakaan. Pendampingan dilakukan satu minggu sekali yaitu hari selasa dan sabtu. Peserta KPM bekerja sama dengan pengurus untuk memantau kegiatan ini setiap harinya. Dan satu bulan sekali peserta KPM mengadakan kumpul bersama untuk membahas buku-buku apa saja yang sudah dibaca selama ini, kemudian para santri bergantian bertukar cerita, mengungkapkan kesan dan pesan apa saja yang bisa diambil dari buku yang sudah dibaca, dan manfaat yang bisa diambil dari buku yang sudah dibaca.

Setelah sampai akhir bulan, peserta KPM bersama pengurus membuat hasil rekapan terkait nama-nama santri yang sudah membaca buku dan mengisi karya di Guru Siana. Dari hasil rekapan tersebut bisa mengetahui seberapa banyak peningkatan terkakit minat membaca para santri ulya di pondok pesantren Ittihadul ummah Jarakan Banyudono Ponorogo.

Hasil Rekapan Literasi Santri Ulya

\begin{tabular}{|c|c|c|c|c|c|c|c|c|c|c|c|}
\hline NO & Nama & $\mathbf{R}$ & BP & 0 & RP & $K$ & $\begin{array}{l}\mathrm{C} / \\
\mathrm{P}\end{array}$ & $\mathbf{P}$ & PA & CA & $\begin{array}{c}\text { Juma } \\
\text { h } \\
\text { Karya }\end{array}$ \\
\hline 1 & $\begin{array}{l}\text { Afnan } \\
\text { Nahrowi }\end{array}$ & & & $\begin{array}{l}\checkmark \checkmark \checkmark \\
\checkmark \checkmark \checkmark \\
\checkmark \checkmark\end{array}$ & & & & $\begin{array}{l}\checkmark \checkmark \checkmark \\
\checkmark\end{array}$ & & & 12 \\
\hline 2 & $\begin{array}{l}\text { Ahmad } \\
\text { Khoiruddin }\end{array}$ & & & $\begin{array}{l}\checkmark \checkmark \checkmark \\
\checkmark \checkmark \checkmark \\
\checkmark \checkmark\end{array}$ & & & & & & & 8 \\
\hline 3 & $\begin{array}{l}\text { Dedi } \\
\text { Sumantri }\end{array}$ & & & & & & & & & & 9 \\
\hline 4 & $\begin{array}{l}\text { Tsani Badrut } \\
\text { Tamam }\end{array}$ & 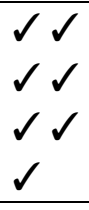 & & $\begin{array}{l}\checkmark \checkmark \checkmark \\
\checkmark\end{array}$ & & & & $\checkmark$ & & & 12 \\
\hline 5 & $\begin{array}{l}\text { Mansur } \\
\text { Daroini }\end{array}$ & & & $\begin{array}{l}\checkmark \checkmark \checkmark \\
\checkmark \checkmark \checkmark \\
\checkmark\end{array}$ & & & & $\begin{array}{l}\checkmark \checkmark \checkmark \\
\checkmark\end{array}$ & & & 11 \\
\hline 6 & Naufal & & & $\checkmark \checkmark \checkmark$ & & & & & & & 12 \\
\hline
\end{tabular}




\begin{tabular}{|c|c|c|c|c|c|c|c|c|c|c|c|}
\hline & Ghufron & & & 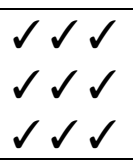 & & & & & & & \\
\hline 7 & $\begin{array}{l}\text { Deni } \\
\text { Setyawan }\end{array}$ & & & & & $\begin{array}{l}\checkmark \\
\checkmark \\
\checkmark \\
\checkmark \\
\checkmark\end{array}$ & $\begin{array}{l}\checkmark \\
\checkmark\end{array}$ & $\checkmark \checkmark$ & $\begin{array}{l}\checkmark \\
\checkmark\end{array}$ & & 12 \\
\hline 8 & $\begin{array}{l}\text { Figur } \\
\text { Firmansyah }\end{array}$ & & & & & & & $\begin{array}{l}\checkmark \checkmark \checkmark \\
\checkmark \checkmark \checkmark \\
\checkmark \checkmark \checkmark \\
\checkmark \checkmark \checkmark\end{array}$ & & & 12 \\
\hline 9 & M. Robiqi & $\checkmark$ & $\checkmark$ & 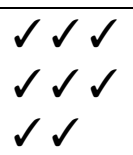 & & $\checkmark$ & & $\checkmark$ & & & 12 \\
\hline 10 & Ilhami Akbar & & & $\begin{array}{l}\checkmark \checkmark \checkmark \\
\checkmark \checkmark\end{array}$ & & & & $\begin{array}{l}\checkmark \checkmark \checkmark \\
\checkmark \checkmark \checkmark\end{array}$ & $\begin{array}{l}\checkmark \\
\checkmark\end{array}$ & & 12 \\
\hline 11 & $\begin{array}{l}\text { Sirojut } \\
\text { Tholibiin }\end{array}$ & $\checkmark$ & $\checkmark$ & $\begin{array}{l}\checkmark \checkmark \checkmark \\
\checkmark\end{array}$ & & $\checkmark$ & & $\checkmark$ & $\checkmark$ & & 10 \\
\hline 12 & $\begin{array}{l}\text { Rohmad } \\
\text { Hidayatullah }\end{array}$ & & & $\checkmark \checkmark$ & & & & $\begin{array}{l}\checkmark \checkmark \checkmark \\
\checkmark \checkmark \checkmark \\
\checkmark \checkmark \checkmark \\
\checkmark\end{array}$ & & & 12 \\
\hline 13 & $\begin{array}{l}\text { Faridatul } \\
\text { Khasanah }\end{array}$ & & & & & $\begin{array}{l}\checkmark \\
\checkmark \\
\checkmark \\
\checkmark \\
\checkmark \\
\checkmark \\
\checkmark\end{array}$ & & $\begin{array}{l}\checkmark \checkmark \checkmark \\
\checkmark \checkmark\end{array}$ & & & 12 \\
\hline 14 & $\begin{array}{l}\text { Kharisma } \\
\text { Nurul } \\
\text { Fauziah }\end{array}$ & $\checkmark \checkmark$ & & $\begin{array}{l}\checkmark \checkmark \checkmark \\
\checkmark \checkmark \checkmark \\
\checkmark \checkmark \checkmark \\
\checkmark\end{array}$ & & & & & & & 12 \\
\hline 15 & $\begin{array}{l}\text { Nurul } \\
\text { Istiqomah }\end{array}$ & $\checkmark$ & $\checkmark$ & $\checkmark$ & $\checkmark$ & $\checkmark$ & $\checkmark$ & $\checkmark$ & $\checkmark$ & $\sqrt{ }$ & 9 \\
\hline 16 & $\begin{array}{l}\text { Ferika } \\
\text { Andani }\end{array}$ & & & $\checkmark$ & & $\begin{array}{l}\checkmark \\
\checkmark \\
\checkmark \\
\checkmark\end{array}$ & & 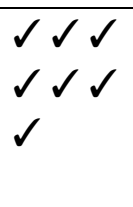 & & & 12 \\
\hline 17 & $\begin{array}{l}\text { Indah Listia } \\
\text { Rahayu }\end{array}$ & $\begin{array}{l}2 \checkmark \\
\checkmark \checkmark \\
\checkmark \\
\checkmark\end{array}$ & & & & $\begin{array}{l}\checkmark \\
\checkmark\end{array}$ & & $\checkmark \checkmark \checkmark$ & $\checkmark$ & & 12 \\
\hline 18 & $\begin{array}{l}\text { Imro'atus } \\
\text { Sholihah }\end{array}$ & & & $\checkmark$ & & $\begin{array}{l}\checkmark \\
\checkmark \\
\checkmark \\
\checkmark\end{array}$ & & $\checkmark \checkmark \checkmark$ & & & 8 \\
\hline
\end{tabular}




\begin{tabular}{|c|l|l|l|l|l|l|l|l|l|l|l|}
\hline $\mathbf{1 9}$ & $\begin{array}{l}\text { Neti } \\
\text { Setiowati }\end{array}$ & & & $\begin{array}{l}\checkmark \checkmark \checkmark \\
\checkmark \checkmark \checkmark \\
\checkmark \checkmark\end{array}$ & & & $\checkmark$ & $\checkmark \checkmark \checkmark$ & & & 12 \\
\hline $\mathbf{2 0}$ & $\begin{array}{l}\text { Siti Faizatur } \\
\text { Rosyidah }\end{array}$ & $\checkmark \checkmark$ & & & & $\checkmark$ & $\checkmark$ & $\checkmark \checkmark \checkmark$ & & $\checkmark$ & 11 \\
& & & & & $\checkmark$ & & $\checkmark$ & & & \\
\hline
\end{tabular}

\section{Keterangan :}

$\begin{array}{ll}\text { 1). R } & \text { : Resensi } \\ \text { 2). BP } & \text { : Best Partice } \\ \text { 3). O } & \text { : Opini/ artikel } \\ \text { 4). RP } & \text { : Reportase } \\ \text { 5). K } & \text { : Kolom } \\ \text { 6). C/P } & \text { : Cerpen/Pentigraf } \\ \text { 7). P } & \text { : Puisi } \\ \text { 8). PA } & \text { : Pantun } \\ \text { 9). CA } & \text { : Cerita Anak }\end{array}$

Berdasarkan tabel diatas dapat diketahui bahwa dengan adanya Guru Siana dapat menumbuhkan literasi pada santri di Pondok Pesantren Ittihadul Ummah. Hal ini diketahui dengan adanya beberapa jenis karya yang telah dibuat oleh para santri. Meliputi:
a. Resensi
= 19 karya
b. Best Partice
= 3 karya
c. Opini/Artikel
$=79$ karya
d. Reportase
= 1 karya
e. Kolom
$=29$ karya
f. Cerpen/Pentigraf
$=6$ karya
g. Puisi
$=77$ karya
h. Pantun
$=7$ karya
i. Cerita Anak
$=2$ karya

Dari hasil rekap diatas diketahui bahwa para santri lebih dominan mengumpulkan karya berupa artikel dan puisi.

\section{KESIMPULAN}

Pelaksanaan pengabdian di pondok pesantren Ittihadul Ummah Jarakan Banyudono Ponorogo terkait budaya berliterasi di jaman yang serba digital ini dapat diselenggarakan dengan baik dan lancar sesuai dengan program kerja yang telah disusun. Tujuan dari program kerja ini, agar pemuda Indonesia terutama santri di pondok pesantren Ittihadul ummah, tidak meninggalkan budaya membaca meskipun jaman semakin canggih terutama dalam bersosial media. Memanfaatkan teknologi yang dimiliki untuk hal-hal yang positif untuk bekal di masa depan. Terus mengembangkan budaya berliterasi hingga bisa menciptakan sebuah karya yang dapat dinikmati oleh khalayak umum. Dan harapanya kelak ketika menjadi alumni santri mampu bersaing dengan dunia luar. Begitu harapan peserta KPM dan pengasuh pondok pesantren Ittihadul Ummah. 


\section{DAFTAR PUSTAKA}

https:www.Kompas.com/skola/read/2020/03/20/120000169/keberagaman-suku-bangsa-di Indonesia?page $=3$

https://www.kanalpengetahuan.com/pengertian-pondok-pesantren

https://www.google.com/search?=daftar+pondok+Pesantren+di+Jawa+timur\&oq=\&aqs=ch rome.2

https://databoks.katadata.co.id/datapublish/2019/09/25/indonesia-negara-denganpenduduk-muslim-terbesar-dunia

Maskur, Abu. "Penguatan Budaya Literasi di Pesantren". IQ (Ilmu Al-Qur'an): Jurnal Pendidikan Islam vol.2, no.1 (2019): 1-16

Makmun, Rodli. Pembentukan Karakter Berbasis Pendidikan Pesantren. Vol. 12 No. 2, (Desember 2014): 214

Maribun. "Minat Membaca dan Implementasinya dalam Bimbingan dan Konseling". ENLIGHTEN, Jurnal Bimbingan Konseling Islam 2, no.2 (2019): 78-84

Mursalin. "Penumbuhan Budaya Literasi Dengan Penerapan Ilmu Keterampilan Berbahasa (Membaca Dan Menulis)". Vol. 3, no. 1 (Juni 2017):33

Moeflich, Hasbullah. Sejarah Sosial Intelektual Islam Indonesia. Jakarta: Pustaka Setia, 2012.

Pedoman KPM-DDR 2021 Institut Agama Islam Negeri Ponorogo, (Ponorogo: LPPM IAIN Ponorogo, 2021), 50.

Rifauddin Machsun, Nur Ariyanti Novi, Aldi Pratama Bagas. "Pembinaan Literasi Di Pondok Pesantren Sebagai Bekal Santri Hidup Bermasyarakat", Info Bibliotheca: Jurnal Terkait Kegiatan Pengabdian Kepada Masyarakat, terkhusus bidang perpustakaan dan IImu informasi, Vol 1, no 2 (Juni 2020): 99-111

Rizqiyah, Baharun. "Melejitkan Ghiroh Belajar Santri Melalui Budaya Literasi di Pesantren", TADRIS: Jurnal Terkait Kegiatan Pengabdian Kepada Masyarakat, terkhusus bidang Pendidikan Islam,15(1),https://doi.org/10.19105/tjpi.v15i1.3048/ 108-117

Salahudin, Nadhir. Panduan KKN ABCD UIN Sunan Ampel Surabaya, (Surabaya: LP2M UIN Sunan Ampel Surabaya, 2015), 46.

Soetomo, Pembangunan Masyarakat. Yogyakarta: Pustaka Pelajar. 2009.

Sayuti, Farid, Imam. Geneologi. Yogyakarta: Nadi Pustaka. 2020

Wawancara dengan Ust. Nastain, Pengasuh pondok Pesantren Ittihadul Ummah 7 Juli 2021 20:00 WIB 